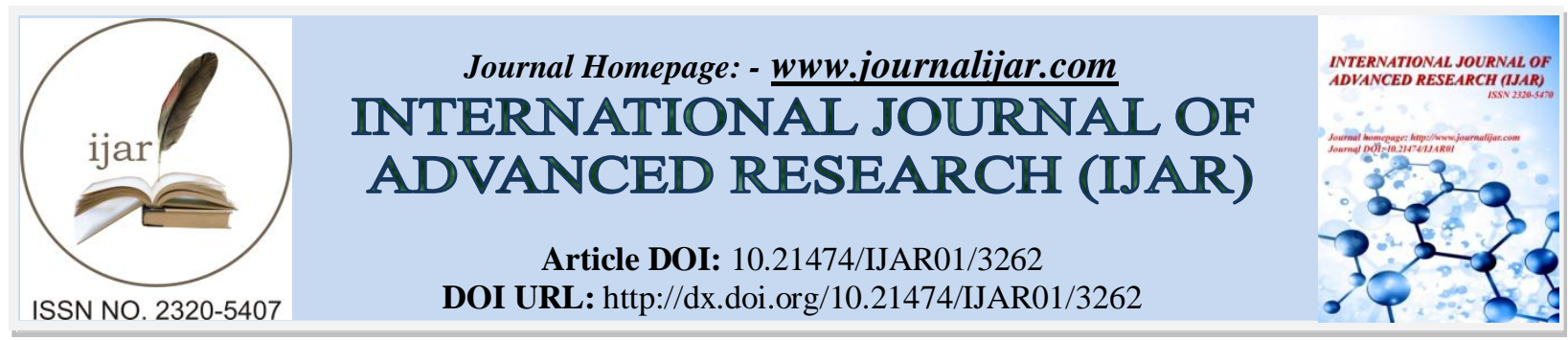

RESEARCH ARTICLE

\title{
ASSIGNING RANK AND WEIGHTAGES TO LANDSCAPE PARAMETERS TO WORK GROUNDWATER POTENTIAL - CASE OF MIDC, BUTIBORI, NAGPUR.
}

Ketan S. Kimmatkar ${ }^{1}$ and Prof. A. J. Sanyal ${ }^{2}$.

1. Associate Professor, IDEAS - Institute of Design Education \& Architectural Studies, Nagpur.

2. Professor \& Ex-Principal, Manoharbhai Patel Institute of Engineering \& Technology, Gondia.

\section{Manuscript Info}

Manuscript History

Received: 21 December 2016

Final Accepted: 25 January 2017

Published: February 2017

Key words:-

Natural Landscape Parameters, Satellite Imagery, G.I.S., Overlays and weight percentages.

\begin{abstract}
In Nagpur region, Central Ground Water Board (CGWB) is monitoring the ground water quality of the district since the last four decades through its established monitoring wells. Ground water trace and exploration has become a cumbersome task in central India in due to irregularities in annual rainfall. The objectives behind the monitoring are to develop an overall picture of the ground water quality of the district. Hydrological traces and possibilities is sought with the help of natural landscape elements like topographical landforms, drainage patterns and watersheds, vegetative land use, soils patterns etc. by image interpretation techniques. The present study was carried out in an area covering around 520.86 sq. $\mathrm{km}$. to deduce the groundwater potential zones in urban industrial fringe area of Nagpur (Maharashtra Industrial Development Corporation - MIDC, Butibori), based on the remote sensing techniques and interpreting and overlaying basic natural landscape parameters.
\end{abstract}

Copy Right, IJAR, 2017,. All rights reserved.

\section{Assigning Rank and Weightages:-}

The weights and rank have been taken considering the earlier works carried out. The maximum value is given to the feature with highest groundwater potentiality and the minimum given to the lowest potential feature. The higher rank factors are assigned to low drainage density because the low drainage density factor favors more infiltration than surface runoff. Lower value followed by higher drainage density. The primary study of slope gradients was carried using top sheet of Survey of India, Nagpur region, while soils data was taken from National Bureau of soil survey and land use planning and remote sensing data was referred from Maharashtra Remote Sensing Applications Centre, Nagpur. The overall analysis is tabulated in following table no.1as: 
Table. No. 1:- Showing various parameters with ranking and weightages.

\begin{tabular}{|c|c|c|c|c|}
\hline Parameter & Classes & Rank & Groundwater prospect & $\begin{array}{l}\text { Weightages } \\
(\%)\end{array}$ \\
\hline Slope Gradients & $\begin{array}{l}\text { Almost Flat (1-3\%) } \\
\text { Gently sloping }(3-5 \%) \\
\text { Sloping (5-10\%) } \\
\text { Steep Sloping }(10-15 \%) \\
\text { Very Steep Sloping }(15-35 \%)\end{array}$ & $\begin{array}{l}5 \\
4 \\
3 \\
2 \\
1\end{array}$ & $\begin{array}{l}\text { Very good } \\
\text { Good } \\
\text { Moderate } \\
\text { Poor } \\
\text { Very poor }\end{array}$ & 40 \\
\hline $\begin{array}{l}\text { Soil Types (based on } \\
\text { sand, silt and clay } \\
\text { contents) }\end{array}$ & $\begin{array}{l}\text { Tamboli } \\
\text { Paunar } \\
\text { J Yenwa } \\
\text { Pangagoan } \\
\text { Jawal }\end{array}$ & $\begin{array}{l}5 \\
4 \\
4 \\
3 \\
2\end{array}$ & $\begin{array}{l}\text { Very good } \\
\text { Good } \\
\text { Moderate } \\
\text { Moderate } \\
\text { Poor }\end{array}$ & 30 \\
\hline Geology & Basalt & 5 & Very good & 15 \\
\hline $\begin{array}{l}\text { Drainage density } \\
(\mathrm{Km} / \mathrm{Km} 2)\end{array}$ & $\begin{array}{l}0-1.2 \\
1.2-2.4 \\
2.4-3.6 \\
3.6-4.8 \\
4.8-6\end{array}$ & $\begin{array}{l}5 \\
4 \\
3 \\
2 \\
1\end{array}$ & $\begin{array}{l}\text { Very good } \\
\text { Good } \\
\text { Moderate } \\
\text { Poor } \\
\text { Very poor }\end{array}$ & 15 \\
\hline
\end{tabular}

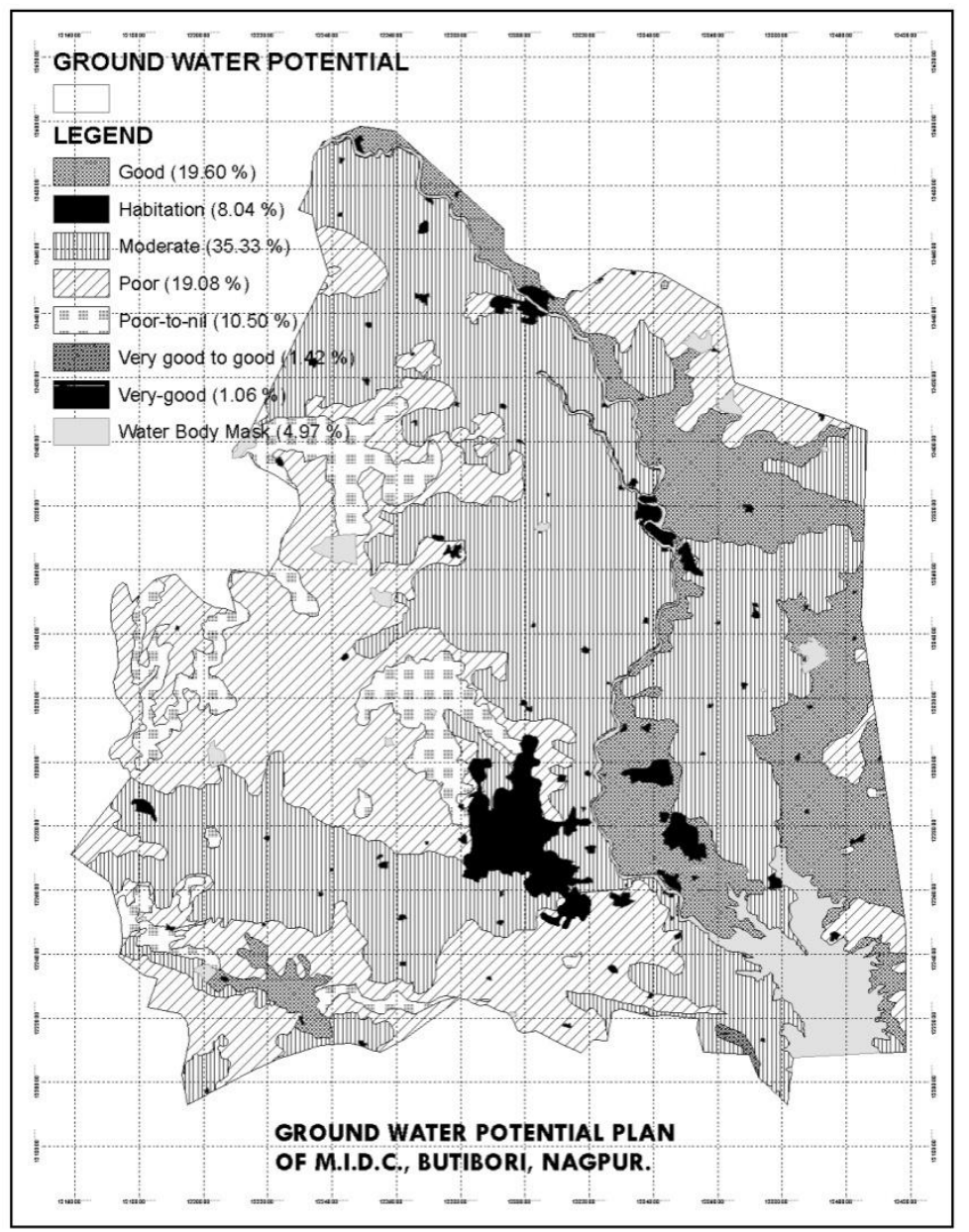

Figure showing Derived Ground Water Potential Plan of Butibori, Nagpur. 
Table 2: Area and Percentage wise Ground Water Potential of Various Zones:

\begin{tabular}{|c|c|c|c|}
\hline Sr. No & Potential zones & Area $\left(\mathbf{K m}^{\mathbf{2}}\right)$ & Area (\%) \\
\hline 1 & Very Good & 5.52 & 1.06 \\
\hline 2 & Very Good to Good & 7.39 & 1.42 \\
\hline 3 & Good & 102.09 & 19.60 \\
\hline 4 & Moderate & 184.03 & 35.33 \\
\hline 5 & Poor & 99.38 & 19.08 \\
\hline 6 & Poor to Nil & 54.69 & 10.50 \\
\hline 7 & Habitation Mask & 41.88 & 8.04 \\
\hline 8 & Water Body & 25.88 & 4.97 \\
\hline
\end{tabular}

\section{Conclusions:}

1. Different thematic layers such as geology, slope gradients, soil types drainage density and the other relevant associated detail give a broad idea about the groundwater prospect of the area. Remote sensing proves to a very effective tool for delineation of groundwater.

2. Geographical information system and remote sensing has proved to be powerful and less time consuming method for determining groundwater potential in parts of MIDC, Butibori, Nagpur.

3. The study reveals that integration of basic natural landscape parameters such as drainage density (with 15 as weight percentage), slope gradients (40\%), geology (15\%) and soil types (30\%) as combination gives first hand information to local authorities and planners about the areas suitable for groundwater exploration.

4. Moderate ground water potential is been observed in one third of the study area while one sixth share is been taken by both good and poor categories. Very Good and Good categories received a negligible share of around $1-2 \%$. The major factor being the dominance of clayey soils with less sand contents having average to flat slope conditions.

5. This groundwater potential information will be useful for effective identification of suitable locations for utilization of water for biomass and other environment friendly development. Further, it is felt that the present methodology can be used as a guideline for further research to determine further combinations using other landscape parameters.

\section{References:-}

1. Gupta, R. P., "Remote Sensing Geology”. 2nd ed. Springer, Berlin, Germany,pp. 460- 477,2003.

2. Deepesh M, Madan K, Jha, Bimal C., "Assessment of groundwater potential in a semi-arid region of india using remote sensing,GIS and MCDM techniques". Water Resource Manage 25:1359-1386, 2011.

3. Groundwater potential Using Remote Sensing and Geographical Information System, In: Mineral and Groundwater resources of Vidarbha, Symp. Vol. pp.25 - 267

4. Hobbs, W. H., "Lineaments of the Atlantic border region”. Geol. Soc. Am. Bull.V. 15, p. 483-506, 1904.

5. Asadi S S, Vuppala P, Reddy M A., "Remote sensing and GIS techniques for evaluation of groundwater quality in municipal corporation of Hyderabad (Zone-V)", India. Int. J Environ Res Public Health, 4(1): 45-52, 2007.

6. Prabir Mukherjee, Chander Kumar Singh and Saumitra Mukherjee "Delineation of Groundwater Potential Zones in Arid Region of India, A Remote Sensing and GIS Approach". Water Resource Manage 26:2643$2672,2011$.

7. Basavaraj Hutti and Nijagunappa.R., "Identification of groundwater Potential Zone using Geoinformatics in Ghataprabha basin, North Karnataka, India". Int.J Geomatics and geosciences 2, 0976-4380,2011.

8. Murugesan B, Thirunavukkarasu R, Senapathi V, Balasubramanian G "Application of remote sensing and GIS analysis for groundwater potential zone in kodaikanal Taluka, South India". Earth Sci. 7(1): 65-75,2012.

9. Anithamary I, Ramkumar T, Venkatramanan S., "Application of Statistical analysis for the hydrogeochemistery of saline groundwater in Kodiakarai, Tamilnadu". Journal of Costal Research, 28(1A):89-98, 2012.

10. Horton, R.E., " Erosional development of streams and their drainage density: hydrophysical approach to quantitative geomorphology". Geol. Soc. Amer. Bull., no.56, pp.275-370,1945.

11. Preeja K. R., Sabu Joseph, Jobin Thomas and Vijith H., "Identification of Groundwater Potential Zones of a Tropical River Basin (Kerala, India) Using Remote Sensing and GIS Techniques". J Indian Soc Remote Sens. 39(1):83-94,2011. 
12. Hsin-Fu Yeh, Cheng-Haw Lee, Kuo-Chin H su, Po-Hsun Chang)., "GIS for assessment of the groundwater recharge potential zone". Environ Geol 58:185-195,2008.

13. Krishnamurthy, J. Venkatesa, K. N., Jayaraman, V. and Manivel, M., "Anapproach to demarcate groundwater potential zones through remote sensing and geographic information system". Int.Journal of Remote Sensing 17,1867-1884,1996.

14. King, L. C., "The study of the worlds plain lands. A new approach in geomorphology". Quarterly journal of Geological society of London 106, pp 101-103,1950.

15. K.S.R. Murthy, E. Amminedu and V. Venkateswara Rao., "Integration of Thematic Maps Through GIS for Identification of Groundwater Potential Zones" J Indian Soc Remote Sens, V.31,No.3,2003.

16. DRM (2003) District Resource Map for Nagpur District, Maharashtra, Geological Survey of India, Central Region

17. L. Yeshodha, H. N. Rajkumaraand, S. Arunachalam., " Modelling of Groundwater Potential Zone Using Remote Sensing and GIS,Krishnagiri District,Tamil Nadu,India”.J Env Research and development,V.5,No.1,2010.

18. M.L.Waikar and AjayChavadekar.,"'Investigation on change detection in Chandpur watershed area by using RS and GIS". International journal Of multidisciplinary and current res.V.2, 2321-3124, (2014).

19. Mohamad Abd manap,saro Lee and Biswajeet Pradhan "Application of probabilistic based frequency ratio model in groundwater potential mapping using Rs and GIS".Arab J Geosci, DOI 10.1007/s12517-012-0795$\mathrm{z}, 2012$.

20. Clark, C.D. and Wilson C., "Spatial analysis of lineaments, computers and Geosciences". V.20, P.1237-1258, 1994.

21. Sparks B.W., "Landform in arid and semi-arid climates; Geomorphology". 2nd edition, (Longman Group Ltd.), pp 335-341,1960.

22. Yammani S., "Groundwater quality suitable zones identification: application of GIS, Chittoor area, Andhra Pradesh, India”. Env Geol, 53(1): 201-210,2007.

23. Subramanian, P.R, Parveen, S, Shastry, B.V and Gwalani, L.G, (1996) Hydrologic features of Nagpur city in the Vidarbha Region of Maharashtra, Mineral and Groundwater Resources of Vidarbha, Symp.Vol., pp. 235 242

24. M.L.Waikar and Aditya P. Nilawar Identification of Groundwater Potential Zone using Remote Sensing and GIS Technique. IJIRSET Vol. 3, Issue 5, May 2014.

25. A GIS Development Asia Pacific, the monthly magazine on GIS, April 2006, Vol.10, Issue 4

26. MRSAC (2001) Training program on remote sensing for social forestry. Dept. of planning, Govt. of Maharashtra, Nagpur, pp. 1-12. 